\begin{tabular}{c} 
Volume and Issues Obtainable at Center for Sustainability Research and Consultancy \\
Sustainable Business and Society in Emerging Economies \\
ISSN: 2708-2504 ISSN (E) 2708-2172 \\
Volume 1: No. 2, December2019 \\
JSRᄃ \\
Journal homepage: www.publishing.globalcsrc.org/sbsee \\
\hline
\end{tabular}

\title{
Relationships Between Attitudes, Subjective Norm and Hiring Intention - Does Age Make a Difference?
}

\author{
${ }^{1}$ Claudia Lau, ${ }^{2}$ Choong Yuen Onn, ${ }^{3}$ Chan Ling Meng, ${ }^{4}$ Thamil Durai a/l Chelliah \\ ${ }^{1}$ Lecturer, Faculty of Business and Finance, Universiti Tunku Abdul Rahman, Malaysia: \\ lausm@utar.edu.my \\ ${ }^{2}$ Asst. Professor, Faculty of Business and Finance, Universiti Tunku Abdul Rahman, Malaysia: \\ choongyo@utar.edu.my \\ ${ }^{3}$ Lecturer, Faculty of Business and Finance, Universiti Tunku Abdul Rahman, Malaysia: \\ chanlm@utar.edu.my \\ ${ }^{4}$ Lecturer, Faculty of Business and Finance, Universiti Tunku Abdul Rahman, Malaysia: \\ thamildc@utar.edu.my
}

\begin{tabular}{l}
\multicolumn{1}{c}{ ARTICLE DETAILS } \\
\hline History \\
Revised format: November 2019 \\
Available Online: December 2019 \\
Keywords \\
Attitudes, Subjective Norm, \\
Intention, Age, The Theory Of \\
Planned Behaviour
\end{tabular}

\section{JEL Classification:}

L25, I12, I19

\begin{abstract}
Malaysia is currently facing a phenomenon where a growing portion of its older population experiencing a decline in their employment participation rate. Simultaneously, most job vacancies are filled by foreign workers as a result of a labour shortage. One of the ways to substitute foreign workers is to utilise skilfully and experienced older workers. However, such requires the willingness of business organizations to hire these workers. Therefore, the main objective of the present study is to predict the relationship of managers' attitudes and subjective norm with their intention to hire older workers, with age as a moderating variable. The Theory of Planned Behaviour was identified to include the age of respondents as the moderator on the relationships between attitudes and hiring intention. Cross-sectional data were collected from managers of business organizations via personal administered quantitative surveys questionnaire. Hypotheses were tested using structural equation modelling (SEM-PLS). The response rate was $78 \%(\mathrm{n}=468)$. The research model accounted for a moderate portion of the variance in overall hiring intention ( $\mathrm{R} 2=0.377)$ and future hiring intention $(\mathrm{R} 2=0.392)$. The findings suggested that: (1) attitudes and subjective norm are related to overall hiring intention and future hiring intention; (2) age has a moderating effect on the relationship between attitudes and overall hiring intention, but there is no moderating effect on the relationship between attitudes and future hiring intention. The empirical result has important implications for human resource strategists, academic researchers and public policymakers as it serves as an additional fuel to combat the nation's acute labour shortage by hiring able and willing older workers.
\end{abstract}

(C) 2019 The authors, under a Creative Commons AttributionNonCommercial 4.0

Corresponding author's email address: lausm@utar.edu.my

Recommended citation: Lau, C., Onn, C. Y., Meng, C. L. \& Chelliah, T. D., (2019). Relationships Between Attitudes, Subjective Norm and Hiring Intention - Does Age Make a Difference?. Sustainable 
Business and Society in Emerging Economies, 1(2), 93-108

DOI: $10.26710 /$ sbsee.v1i2.1014

\section{Introduction}

One of the real issues that confronted Malaysia on the realization of an aspired developed and the highincome nation is the shortage of labour and talents. In Malaysia, the gradual increase in the ageing population against declining total population growth, and a rise in the 15-year-old and above age groups indicated a continually ageing population growth is to be expected in the coming years. In terms of future demographic development, by 2035, Malaysia's older population aged 60 and above is expected to reach $15 \%$ of its population which brings Malaysia into the ageing nation category (Tenth Malaysia Plan [MP], 2011-2015). Additionally, in 2016, Bank Negara's report confirmed an increased reliance on foreign workers in the labour-intensive sectors (King, 2017); indicates that the local workforce participation rate had reduced. This effectively suggests that future jobs are likely to be filled by foreign labour instead of utilizing local older workers. As such, the Eleventh MP (2016-2020) made a deliberate point of the gradual reduction on the reliance on foreign labour and to limit the percentage of foreign labour in a company to no more than $15 \%$.

Older workers have emerged as an important market segment since they are much healthier, better educated and lived longer compared to their predecessors. Therefore, one potential labour source expected to ease the labour problem should be the skilful, experienced and able older workers. These older workers are needed to increase their participation in the labour force and to extend their own working lives simultaneously. The question as to whether older workers are hired eventually is very much dependent on hiring managers who played a crucial role in the recruitment and selection of their workforce.

This study attempted to predict managers' hiring intention of older workers based on the modified theory of planned behaviour (TPB) (Ajzan, 1991). The present study used intention-based human behaviour with the original variables of attitudes (ATT) and subjective norm (SN) as investigative determinants of intention (INT) to hire older workers. The age of managers was designed as a moderator on the relationship between managers' attitude towards older workers and their intention to hire older workers. It is noted that even when managers' intention to hire is established. However, there are instances where their immediate intention is not possible. Therefore, for practical reasons, managers' intention to hire older workers is divided into an overall intention and a future intention. A future intention referred to managers' intention within 12 months from the time of their participation in the survey. The division is deemed necessary as managers who have positive intentions to hire older workers may not have the resources or means to immediately hire older workers. Nonetheless, they still possess that overall intention. Some managers identified hiring older workers as their priority may hire an older worker at the very instant when and where opportunity avails.

The targeted respondents are hiring managers from 11 industries located in Perlis, Kedah, Pulau Pinang, Kuala Lumpur, Melaka, Negeri Sembilan, Perak, Johor and Selangor in West Malaysia (The 9 locations). The older workers referred to Malaysian, non-executive level employees aged 50 and above, both males and females of all ethnicities, and are either in employment or active job seekers.

\section{Literature Review}

\subsection{Behavioural Intention}

Behavioural intention (BI) is defined as a measure of relationships between an individual and some actions, and how hard this individual is willing to perform the actions. The behavioural intention is his/her decision or commitment to perform a given behaviour. When an intention to perform a particular act is high, the likelihood of such actions is equally high (Ajzen, 1985). However, the intention to perform a particular behaviour can be transformed given unexpected factors. As advanced by Park and Yang (2012), the influence by various factors on behavioural intention need not be equal at all time because within these determinants, there can be conflict among them in influencing the behavioural intentions. To some 
extent, even if the intention was high, some actions were dependent on the availability of resources such as time, money, skills or opportunity. In any event, the relative weights of attitudes, subjective norm and perceived behavioural control should measure the behavioural intention (Kumar, 2019).

Behavioural intention is also used to understand the actual behaviour in areas such as intention to quit smoking (e.g. Soulakova, Li \& Crokett, 2017), intention to quit alcohol (e.g. Paswan, Gai, \& Jeon, 2015); intention to hire workers (e.g. Ang, Ramayah \& Amin, 2015; Fraser, Ajzen, Johnson, Hebert \& Chan, 2011; Lau, Choong \& Wong, 2018; Lu \& Kao, 2010); intention to retain workers (e.g. Salah, \& Habtoor, 2015). Therefore, it is appropriate to assume that intentions predict an individual's actual behaviour (Fichten et al., 2014). In this present study, behavioural intention refers to a measure of relationships between the determinants of the responding managers and their willingness to perform the actions of hiring older workers.

\subsection{Attitudes}

Attitude is an index of the degree to which a person liked or disliked an object, where "object" in the generic sense referred to any aspect of the individual's world. A person's overall attitude is determined by his beliefs about that attitudes object (Ajzen \& Fishbein, 2000). Accordingly, attitudes are defined as the extent to which an individual regarded a set of behaviour as favourable or otherwise (Ajzen, 1991). If an individual's regard to performing certain behaviour is favourable to him, and that the greater the favour is to him, his attitudes influence his intention, and hence he has a great intention towards that particular performance. In Hansen, Jensen and Solgaard (2004), consumers' attitudes were found to be the most important predictor of intention, there was a strong relationship between them. In Lu, Kao \& Hsieh (2011), respondents' positive attitudes towards older people were found to be strongly related to the intention to hire older workers. Research indicated that negative attitudes have significance on low hiring intention resulted in hiring managers rated older workers lower as opposed to rating younger workers (Lau et al, 2018; Ng \& Feldman, 2013; Karpinska, Henkens \& Schippers, 2013). Such being the case, managers' judgments on age-related characteristics without taking into account of older workers' actual knowledge, skills, and abilities, such often created a barrier that prevented these workers' mobility within the labour market (Abrams, Swift \& Drury, 2016; Earl, Taylor \& McLoughlin, 2017).

Attitudes are, therefore, a good predictor of intention, and thus a positive relationship between affective and instrumental attitudes and hiring intention is expected by measuring an individual's attitudes towards a certain behavioural intention. In this present study, attitudes are defined to include favourable and unfavourable consequences of managers in their hiring of older workers. Hence, the research question no. 1 is: "Whether attitudes towards older workers is related to managers' intention to hire older workers?" The hypotheses are formulated as follow:

H1a: There is a relationship between attitudes and managers' overall intention to hire older workers.

H1b: There is a relationship between attitudes and managers' future intention to hire older workers.

\subsection{Subjective Norm}

A subjective norm referred to an individual's intention to perform a certain behaviour if he perceived that people important to him think that he should or should not perform a behaviour in question (Ajzen, 1991). In that sense, the subjective norm is a social injunctive norm because it concerns a person's perceived social pressures from someone important to him and that on their approval; he performed the particular task (White, Smith, Terry, Greenslade \& McKimmie, 2009). Therefore, subjective norm is a form of beliefs where an individual believed in certain groups of people who are important to him. The expectation of such important or closed persons often add pressure onto the desired behaviour, hence, high subjective norm often results in high willingness to perform the desired action (Vansteenkiste, Deschacht \& Sels, 2015). In Lau et al. (2018) and Lu et al. (2011), subjective norm was found to be 
strongly related to managers' intention to hire older workers. Although there are several studies indicated a positive relationship between subjective norm components and intentional behaviour; however, negative relationships lacked trust among colleagues and management (Nedkovski, Guerci, De Battisti \& Siletti, 2017).

In this study, subjective norm is defined to include a hiring manager's perception of the important reference groups he valued, believed that he ought to hire older workers or otherwise. From the research question no.2, "Whether subjective norm is related to managers' intention to hire older workers?" The hypotheses are formulated:

H2a: There is a relationship between subjective norm and managers' overall intention to hire older workers.

H2b: There is a relationship between subjective norm and managers' future intention to hire older workers.

\subsection{The Moderating Role of Managers' Age}

Respondents' age is a demographic variable. Their age provides some information on the knowledge and experience of the subject matter (Lev, Wurm, \& Ayalon, 2018). Chiu, Chan, Snape \& Redman (2001) revealed that respondents from different age groups responded differently concerning their attitudes towards older workers. This finding did not differ from Hassell and Perrewe (1995). Traditionally, it was common in organizations that older employees supervised younger employees; however, such patterns have changed in recent times mainly due to the need to increase organizational overall performance and to enhance human resource merit-based reward systems. Hence, younger workers are promoted to managerial positions, and they, in turn, supervised older subordinates (Kunze \& Menges, 2016).

In Laditka, Fischer, Laditka and Segal (2004), the findings showed that an older age group respondents (aged 60 and above) rated another older targeted group better than respondents from the young and middle age groups, and this effectively indicated that older persons, both males and females, generally had more positive attitudes towards their cohorts. This study found that age influenced the in-group relationships, where older respondents favoured their cohorts. This is supported by Heyma, Werff, Nauta \& Sloten, (2014) that older managers were more ready to hire older workers. From a positive side, such managers could probably increase older workforce labour participation. Generally, the age of an individual has an important effect on his behaviour (Liébana-Cabanillas, Sánchez-Fernández \& MuñozLeiva, 2014). Research has shown that managers of different age groups have different profiles in their leadership styles in managing their subordinates; in that, managers of an older age group are better able to successfully resolve issues in their lives, to have a greater sense of meaning and satisfaction than managers of a younger age group. Besides, they also consulted more widely and favoured more participation (Ang \& O, 2012). Studies also suggested that younger respondents were not in favour of older workers, whereas the older cohort preferred older workers (Fisher, Truxillo, Finkelstein \& Wallace, 2017). Likewise, in Brothers, Miche, Wahl and Diehl (2017), Mohd Isa and Wong (2015) and Muhamad Hanapiyah, Daud and Wan Abdullah (2018), age have moderating effects.

On the contrary, in Lu et al. (2010), there was no difference between age groups of respondents as far as attitudes were concerned, as these respondents generally had negative attitudes towards older people, including the unwillingness to take up employment involved in providing services to older people. As the effect of age found in past studies varied, that makes the age of respondents crucial to moderate their intention to hire older workers. In Baron and Kenny (1986: 1174, 1178), a moderator is described as either a qualitative or a quantitative variable that "affects the direction and/or strength of a relationship between an independent or predictor variable and a dependent or criterion variable." Thus, a moderator variable can create an impact on the dependent variable by specifying the direction or a level of strength. 
Since there are mixed results and it is difficult to find one consensus conclusion or defences deliberated on the moderating effect of age; as such, this present study is determined to test the moderating effect of managers' age on their attitudes and intention to hire older workers. The research question no.3 developed is: "Whether the age of managers has any impact on the relationship between their attitudes towards older workers and intention to hire them?" Following Dawson (2014) that moderation is hypothesized in advance; the following hypotheses are formulated:

H3a: Managers' age has an impact on the relationship between attitudes towards older workers and overall hiring intention.

H3b: Managers' age has an impact on the relationship between attitudes towards older workers and future hiring intention.

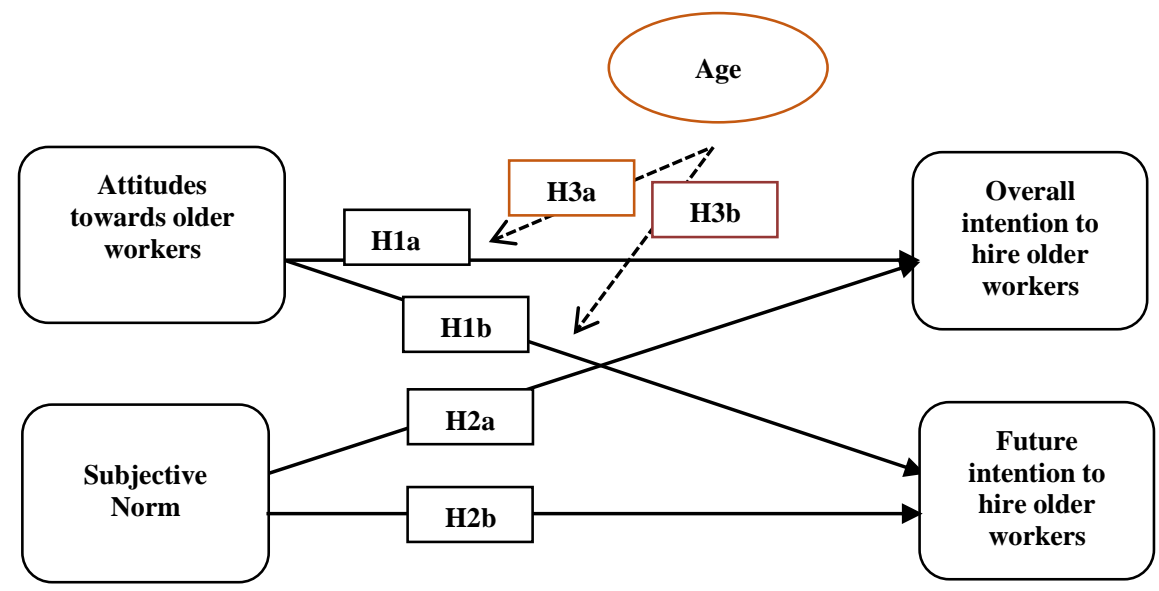

Figure 01: Research Model Showing the Hypothesized Relationships

\section{Methodology}

\subsection{Measurement Scale}

The present study is a quantitative survey with 55 questionnaires personally administered to respondents at their workplaces. Scales used are nominal scales, ordinal scales, semantic differential scales and Likert scales. A set of 4 semantic differential scales on attitudes questions was developed based on the recommendations from Ajzen (2002b). Respondents are asked to select from a series of 7-point bipolar rating scales ranging from negative to positive. For subjective norm, 5 questions on a 7-point Likert scales were adapted from Ajzen. On the overall intention, respondents were asked to rate their agreement or disagreement with hiring older workers on 4 questions on 7-point Likert scales. On the future intention, 3 questions were adapted from Lu et al. (2011) by including 12 months into each of the questions and that respondents were to rate their likelihood or unlikelihood according to the statements on 7-point Likert scales. Age was a moderator between responding managers' attitude and their hiring intention. Managers' age is divided into 4 categories. Group A referred to those aged 30 and below; group B from 31 to 40; group $\mathrm{C}$ from 41 to 50 and group D 51 and above. One question on nominal scales was listed which required respondents to select the age group most appropriate to them.

\subsection{Data Processing}

There was no missing data from the returned questionnaires. All the questionnaires were arranged according to regions and industries and coded accordingly. The numerical code was assigned to each of the Likert scales where the values ranged from Strongly Disagree=1, Somewhat Disagree=2, Disagree=3, Neutral=4, Agree=5, Somewhat Agree=6, and Strongly Agree=7. A data file was created in IBM software package (SPSS) version 23. The CSV file format of the data set was uploaded to the Smart Partial Least Squares-Structural Equation Modelling (SmartPLS 3) (Ringle, Wende \& Becker, 2015) for PLS path 
modelling and analysis. The scale-items for the constructs were modelled with reflective indicators. To perform the PLS analysis, the two-stage approach was adopted (Hair, Hult, Ringle, \& Sarstedt, 2014).

\subsection{Data Analysis}

The PLS approach is adopted to perform the structural equation modelling by testing the measurement model and the structural model. The software package SmartPLS, version 3 (Ringle, et al, 2015) was used to perform the data analysis. PLS is appropriate for estimating complex cause-effect relationship models with latent variables. Chin (1998a) stated that PLS can be applied in confirming the theory or developing a theory by exploring relationships between variables. In the two-stage approach, the first approach was the building and testing of a measurement model, followed by the building and testing of a structural model (Hair et al., 2014).

\subsection{Factor Loadings}

Factor loadings were conducted to test the indicator's reliability. From Table 01 below, all the loadings for attitudes and future intention were high at 0.9 level. For subjective norm and overall intention, all the loadings were above 0.7 level. All the items' values for the 4 variables were above the 0.7 thresholds (Hair et al., 2014); indicated that all the items were of relatively high standardized loadings and high significance (Kline, 2011).

\subsection{Reliability}

Cronbach's alpha values for each of the measurements were greater than 0.80 and all the Cronbach's alpha values indicated high internal consistency of the measurement instrument for the study (Hair et al., 2014). Given the limitation in Cronbach's alpha, composite reliability was applied for its ability to take into account the different outer loadings of the indicators variables (Hair et al.). From Table 01, the group of constructs with values above 0.9 level are attitudes, subjective norm and future intention. The overall intention is above the 0.8 level. The composite reliability for all the values above the 0.80 indicated that the latent constructs are all accepted and demonstrated a high level of internal consistency reliability among them (Hair et al.). From both sets of the tested values for internal consistency reliability, there were only some slight differences between them. Therefore, it is concluded that all the values are of a high level of reliability level.

Table 01. Item Loadings and Internal Consistency Reliability

\begin{tabular}{|c|c|c|c|c|}
\hline Item & $\begin{array}{l}\text { Factor } \\
\text { Loadings }\end{array}$ & Constructs & $\begin{array}{l}\text { Cronbach' } \\
\text { Alpha }\end{array}$ & $\begin{array}{l}\text { Composite } \\
\text { Reliability }\end{array}$ \\
\hline A1 & 0.911 & \multirow[t]{4}{*}{ Attitudes } & \multirow[t]{4}{*}{0.932} & \multirow[t]{4}{*}{0.951} \\
\hline $\mathrm{A} 2$ & 0.926 & & & \\
\hline A3 & 0.900 & & & \\
\hline A4 & 0.909 & & & \\
\hline SN1 & 0.783 & \multirow{5}{*}{$\begin{array}{l}\text { Subjective } \\
\text { Norm }\end{array}$} & \multirow[t]{5}{*}{0.908} & \multirow[t]{5}{*}{0.932} \\
\hline SN2 & 0.847 & & & \\
\hline SN3 & 0.891 & & & \\
\hline SN4 & 0.905 & & & \\
\hline SN5 & 0.849 & & & \\
\hline OIN1 & 0.829 & \multirow{4}{*}{$\begin{array}{l}\text { Overall } \\
\text { Intention }\end{array}$} & \multirow[t]{4}{*}{0.804} & \multirow[t]{4}{*}{0.871} \\
\hline OIN2 & 0.811 & & & \\
\hline OIN3 & 0.816 & & & \\
\hline OIN4 & 0.708 & & & \\
\hline FI1 & 0.947 & \multirow{3}{*}{$\begin{array}{l}\text { Future } \\
\text { Intention }\end{array}$} & \multirow[t]{3}{*}{0.917} & \multirow[t]{3}{*}{0.947} \\
\hline FI2 & 0.914 & & & \\
\hline FI3 & 0.917 & & & \\
\hline
\end{tabular}




\subsection{Validity}

The present research is a reflective measurement model where construct validity is essential to the perceived overall validity of the test. Reflective measurement model's validity assessment focused on convergent validity and discriminant validity. To check the convergent validity, the average variance extracted (AVE) values on all latent variables were examined.

Table 02: Outer Model's Validity

\begin{tabular}{|l|l|l|l|}
\hline Constructs & $\begin{array}{l}\text { Convergent } \\
\text { Validity } \\
\text { (AVE) }\end{array}$ & $\begin{array}{l}\text { Square } \\
\text { root } \\
\text { AVE }\end{array}$ & $\begin{array}{l}\text { Discriminant } \\
\text { Validity? }\end{array}$ \\
\hline Attitudes & 0.830 & 0.911 & Yes \\
\hline $\begin{array}{l}\text { Future } \\
\text { Intention }\end{array}$ & 0.857 & 0.926 & Yes \\
\hline $\begin{array}{l}\text { Overall } \\
\text { Intention }\end{array}$ & 0.628 & 0.792 & Yes \\
\hline $\begin{array}{l}\text { Subjective } \\
\text { Norm }\end{array}$ & 0.733 & 0.856 & Yes \\
\hline
\end{tabular}

From Table 02, all values met the acceptable level (Bagozzi \& Yi, 1988). As such, the variables highly correlated and this indicated a sufficient degree of convergence validity, meaning that the latent variable in the study explained more than half of its indicators' variance. There was a strong convergent validity since all the factor loadings were more than 0.50 minimum AVE value for each construct. The results provided on all other loadings evident distinctive, unidimensional scales of constructs from each other. Internal convergent validity is satisfied. Also from Table 02 above, all square root values for latent variables attitudes (0.911), future intention (0.926), overall intention (0.792), and subjective norm (0.856) were below the value of 1 . Hence, the square root values for all these latent variables indicated that discriminant validity is well established between all the constructs.

\subsection{Sample and Response Rate}

There was no prior name list available on managers responsible for hiring workers for their organizations from the 11 industries and the 9 locations, also, no list on companies or types of businesses and the locations where these managers could be found and contacted. Thus, non-probability sampling was the best way to obtain respondents' information (Zikmund, Babin, Carr, \& Griffin, 2010).

To accurately determine the sample size before conducting the survey, the minimum sample size recommended by the "10 times" rule (Hair et al., 2014) and by G*Power were applied accordingly. Thus the number of 468 respondents in this present study had far exceeded the minimum sample size required and this number should be large enough to capture the largest casual relationships in the structural model. Furthermore, the sample size of 468 had also fulfilled the population requirement for it to be representative (Sekaran \& Bougie, 2016).

A total of 600 sets of questionnaires were personally distributed to targetted respondents at their workplaces. 468 usable responses were from 189 female (40.4\%) and 279 male (59.6\%). In total, there was a response rate of $78 \%$. The breakdowns of responses were: Johor (10.7\%), Kedah (10.7\%), Melaka (10.9\%), Negeri Sembilan (10.7\%), Perak (11.3\%), Perlis (8.1\%), Pulau Pinang (10.9\%), Selangor $(11.8 \%)$, and Kuala Lumpur (15\%). The highest age groups were from 31 to 40 (37\%), 41 to 50 (28.8\%) categories. On educational attainment, $63.5 \%$ have either diploma or bachelor degrees. The respondents mainly held positions such as human resource or administration managers (26.7\%), company director (23.9\%), followed by production managers $(21.8 \%)$. The highest number of years of service was those with 1 to 5 years $(32.1 \%)$ category, followed by 6 to 10 years $(27.45 \%)$ and 21 years and above $(10.9 \%)$. 
Majority of the respondents came from wholesale and retail trade (26.5\%), accommodation and food service activities (13.2\%), manufacturing (12\%) and $11.5 \%$ from financial services.

\section{Findings and Discussion}

\subsection{Effect Sizes and Predictive Relevance}

According to Hair et al. (2014), the primary evaluation criteria for the structural model is the measured value of $R^{2}$ and the level and significance of the path coefficients. In the assessment of $R^{2}$ value, the value has to be high enough to achieve a minimum level of explanatory power; where this minimum $R^{2}$ level is deemed adequate for the variance to explain a particular endogenous construct. According to the rule of thumb applied to the acceptability of $R^{2}$, future intention (0.392), overall intention (0.377) and subjective norm (0.339) were considered moderate, whereas attitudes (0.050) was weak (Hair et al, 2014). This effectively meant that the variables of attitudes and subjective norm had substantially explained $39.2 \%$ of the variance in future intention and $37.7 \%$ in overall intention. Based on the results, future intention, overall intention and subjective norm demonstrated a moderate predictive accuracy. Following the $f^{2}$ rule of thumb for effect size; attitudes $(0.253)$ had a moderate predictive impact on future intention, while subjective norm (0.086) had small predictive impacts on future intention. Also, subjective norm (0.151) had a moderate predictive impact on overall intention, while attitudes (0.094) had small predictive impacts on overall intention.

\subsection{Testing Hypotheses for Research Question no. 1}

Two hypotheses in Research Question no. 1 were tested accordingly. The summarised results and their significance levels are presented in Table 03.

Table 03: Summary of Significance Testing Result of the Structural Model Path Coefficients (RQ: $1,2 \& 3)$

\begin{tabular}{|l|l|l|l|l|l|}
\hline RQ & Hypothesis & $\begin{array}{l}\text { Path } \\
\text { coefficient } \\
\boldsymbol{\beta} \text { value }\end{array}$ & $\begin{array}{l}\boldsymbol{t} \\
\text { Value }\end{array}$ & $\begin{array}{l}\text { P } \\
\text { Values }\end{array}$ & $\begin{array}{l}\text { Significant } \\
\text { Levels }\end{array}$ \\
\hline \multirow{2}{*}{1} & H1a & -0.263 & 5.494 & 0.000 & Yes*** \\
\cline { 2 - 6 } & H1b & -0.426 & 9.730 & 0.000 & Yes*** \\
\hline \multirow{2}{*}{2} & H2a & 0.340 & 5.849 & 0.000 & Yes*** \\
\cline { 2 - 6 } & H2b & 0.253 & 4.975 & 0.000 & Yes*** \\
\hline \multirow{2}{*}{3} & H3a & 0.109 & 2.605 & 0.009 & Yes*** \\
\cline { 2 - 6 } & H3b & 0.003 & 0.067 & 0.947 & NS \\
\hline
\end{tabular}

Note: $\mathrm{NS}=$ not significant, $* \mathrm{p}<.10, * * \mathrm{p}<.05, * * * \mathrm{p}<.01$

On the $\beta$ value for $\mathrm{Hla}$, the $\beta$ value $(-0.263)$ was above the -0.20 threshold. The relationship was moderate. For a negative path coefficient, ATT effected negatively to OINT such that when ATT increased by $1 \mathrm{SD}$, OINT decreased by 0.263 in SD. A negative path coefficient was interpreted in the same way as a positive standardized regression coefficient. The std. error $\mu=0.048$, the empirical $t$ value $=5.494$ was larger than the theoretical value of 2.58; therefore the relation between ATT and OINT was significant @ p<.01 confidence level (Hair et al., 2014). Hence, there was significant evidence that Attitude had a negative relationship with Overall Intention. H1a is supported.

On $\mathrm{H} 1 \mathrm{~b}$, the $\beta$ value (-0.426) was above the -0.30 threshold (Chin, 1998b) indicated a strong relationship. ATT effected negatively to FINT when ATT increased by 1 SD, FINT decreased by 0.426 in SD. The std. error $\mu=-0.426$, the empirical $t$-value (9.730) was larger than the theoretical value of 2.58; therefore the relationship between ATT and FINT was significant @ $\mathrm{p}<.01$ confidence level (Hair et al., 2014). Hence, there was significant evidence that ATT had a negative relationship with FINT. H2b is supported. 
Intention to hire was supportive of Fraser et al. (2011) and Lu et al. (2011), where a great contribution to the prediction of intention came from attitudes. In this present study, managers from older-age groups had a more positive attitude towards older workers, as opposed to managers from a young-age group, and the influence of such positivity on the intention to hire supported earlier studies (e.g. Hassell \& Perrewe, 1995; Lau et al., 2018). In that sense, managers were more likely to hire or retain older workers in their organizations. Additionally, older managers' positive attitudes also supported the in-group's biased behaviour. From the 2 hypotheses tested, it is concluded that Research Question no. 1 on whether attitudes towards older workers is related to managers' intention to hire older workers is answered.

\subsection{Testing Hypotheses for Research Question no. 2}

The path coefficient $\beta$ value $=0.340$ for $\mathrm{H} 2 \mathrm{a}$ was above the 0.30 threshold indicated a strong relationship. Hence it was accepted and statistically significant (Chin, 1998b). The std. $\mu=0.058$, and the empirical $t$ value (5.849) was significant @ $\mathrm{p}<.01$ confidence level (Hair et al., 2014). Hence, there was significant evidence that SN had a positive relationship with OINT. H2a is supported.

On $\mathrm{H} 2 \mathrm{~b}$, the path coefficient $\beta$ value $(0.253)$ had a moderate relationship, hence it was accepted and statistically significant (Chin, 1998b). The std. $\mu=0.051$, and the empirical $t$-value (4.975) was significant $@ \mathrm{p}<.01$ confidence level (Hair et al., 2014). Hence, there was significant evidence that SN had a positive relationship with FINT. H2b is supported.

The relationships established in both $\mathrm{H} 2 \mathrm{a}$ and $\mathrm{H} 2 \mathrm{~b}$ were supportive of Ang et al. (2015), Fraser et al. (2011) and Lu et al. (2011) respectively where the subjective norm was a great contributor to intention. The established relationships in both these hypotheses signified that the Research Question no.2 on whether subjective norm is related to managers' intention to hire older workers is answered.

\subsection{Testing Hypotheses for Research Question no. 3}

On the hypothesized path relations of age as a moderator on the relationship between ATT and OINT, the path coefficient (0.109), t-value (2.605) and p-value (0.009) were significant@ @ $<0.01$ level (Hair et al., 2014). H3a is supported.

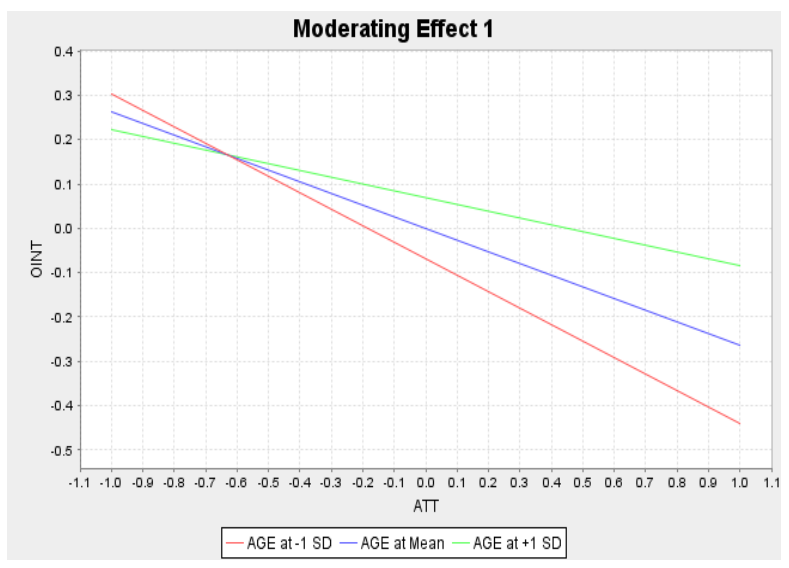

\section{Figure 02: Moderating Effect of Age on the ATT and OINT}

The path coefficient $\beta=0.109$ indicated a positive relationship. From Figure 02, all 3 sets of lines began from above the mean (0.107) and gradually moved down to below the mean. With the red line being the lowest, the blue line in the middle indicated a regular effect of age on attitude (ATT) and overall intention (OINT). The green line was the highest closest to the mean $@+1$ SD active coping. Therefore, on the interaction term ATT*AGE, it has a positive effect on OINT, t-value (2.605), p-value (0.009) were significant@0.01 confidence level. The path relation of Age to OINT (0.070) and the effect size of moderating effect from F-square (0.019) were below 0.10, indicating that the size was very small and rendered it not meaningful. Therefore, it is concluded that there existed a positive moderating effect of 
age on the relationship between ATT and OINT although the effect size was small. H3a was supported which indicated that managers' attitudes and their overall intention to hire older workers were moderated by their age. The moderating effect confirmed Bal, De Lange, Jensen, Van Der Velde (2008) where age was found to have a moderating effect on exogenous and endogenous variables.

On H3b, the path coefficient $\beta(0.003)$ was below the 0.20 threshold; rendered it unacceptable and statistically insignificant (Chin, 1998b). Both t-value (0.067) and p-value (0.947) were also insignificant and as such $\mathrm{H} 3 \mathrm{~b}$ is not supported.

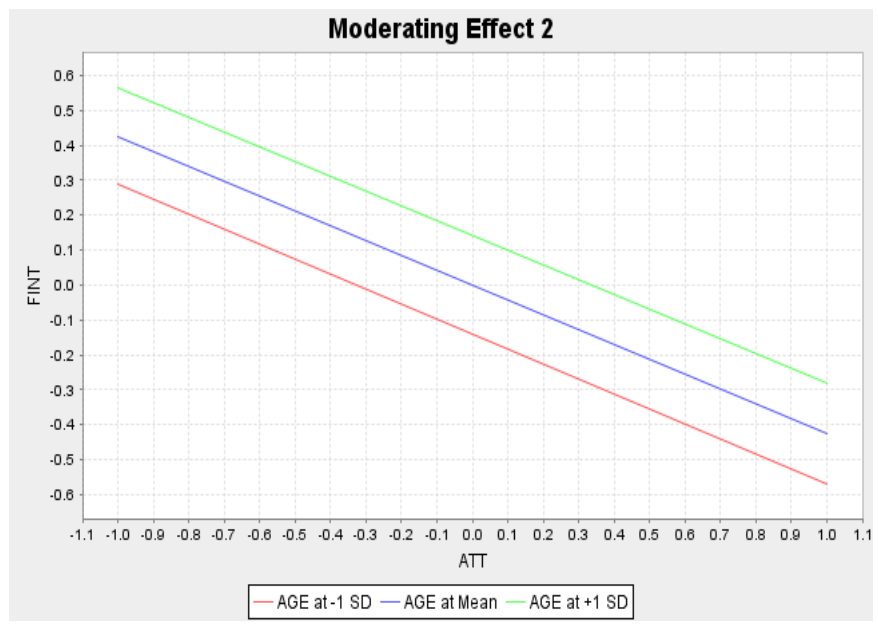

Figure 03: Moderating Effect of Age on the ATT and FINT

In the moderating effect, the path coefficient $\beta(0.003)$, t-value (0.067) and $p$-value (0.947) indicated a positive relationship but it was insignificant. In Figure 03, all 3 sets of lines began from above the mean and gradually moved down to below the mean, the red line is the lowest, the blue line in the middle, whereas the green line was the highest and closest to the mean $@+1$ SD active coping. The blue line indicated the regular effect of age on ATT and FINT. Therefore, a positive effect on FINT. However, the positive slope at low values of the moderator gradually moved towards a negative slope at high values rendered the moderating effect insignificant.

The F-Square of path relation of Age to FINT (0.030), the moderating effect at 0.000 was below 0.10 indicated no moderating effects. Therefore, although there was evidence of a positive significant relationship of Age on paths between Age and FINT, there was no moderating effect of age on the relationship between ATT and FINT. This confirmed that H3b is not supported. This finding indicated that age did not play any interactive role in influencing managers' attitude and their future hiring intention of older workers. Furthermore, this finding supported $\mathrm{Lu}$ and Kao (2010) on no difference between the age groups of respondents as far as the attitude was concerned.

Since only H3a is supported, therefore, it is concluded that Research Question no.3 is partially answered.

\section{Theoretical Implication and Contribution}

The overall quantitative findings added value to the knowledge of Malaysian research literature on the ageing workforce. The answers to the research questions provided a real meaning in terms of hiring older workers and the future utilization of the ageing workforce. Additionally, it was the understanding of age as a moderator on the relationships between attitudes and intention. The moderating effect of age suggested that intention to hire can be moderated by the age of managers in business organizations. From the literature reviewed thus far, age as a moderator on hiring intention of older workers has not been evident in local literature.

The present study's theoretical contribution and theory development are that this modified TPB model 
provided a multi-component construct model in understanding the various determinants of the hiring intention of older workers. The model can be used as a starting point for future research on the issues on or related to the employment of older workers and its impact on Malaysian employment practices. Therefore, this present study adds to knowledge and provides a new avenue of research surrounding the hiring intention in the local scene. The effect of managers' age on attitude and intention may be correlated with other variables such as managers' job positions, length of employment in their organizations, and the manpower strategical choices. Nevertheless, because of the little research on age as a moderator on the hiring of older workers, this present result is deemed helpful to contribute to future study.

\section{Managerial Implication and Contribution}

Generally, the employment and training of older workers have not been a popular subject for discussion in many organizations. From the empirical results, although there are positive relationships between attitudes, subjective norm and managers' hiring intention, these do not diminish the problem of overcoming age discrimination and negative attitudes of managers. All these are still potential areas within business organizations, which if left unattended, would affect managers' hiring intention of older workers, and face the ageing issues of the organizations' current workforce, as all these would render the management of a diversified workforce even more difficult.

The implications for business organizations management are that managers need to be attentive to their organizational climate concerning an older workforce, and formulate human resource policies, such as age awareness policies. To improve the understanding and awareness of the ageing trends and utilization of older workers, the management needs to recognize the importance and benefits of a diversified workforce, to take steps to understand factors which influence managers' intention to hire older workers. Management will need to consider a holistic approach to change managers' intentional behaviour with programs design to drive changes in the managers' beliefs system and their general attitudes towards older workers (Rudolph, Toomey, \& Baltes, 2017). With a larger degree of managers' positive intention, the more likelihood of hiring can be expected.

Consideration must be given to the management to address the older workforce in their organizations, at the same time to formulate human resource strategies and policies targeted for effective recruitment and retention of older workers; in most business organizations, it is common to see that those who formulate and implement organizations' policies on employees' welfare, recruitment, and hiring decisions are more often than not, the middle-age group managers. If these middle-age managers hold negative attitudes on older workers and have no intention to hire them, then the business organizations will likely resort to recruiting part-time workers or continue to hire foreign workers. The issue of demographic changes and ageing society have created a large pool of readily available older workforce that must not be ignored. Management has to take note that this is not a peculiar phenomenon in Malaysia, but a worldwide issue.

The significant contribution from this study is the importance of knowing the 2 predictors' relationships with managers' hiring intention. From a business organization's perspective, this knowledge gives organizations opportunities to support managers' intention and lead to accomplishing the organization's goals with vacancies be filled up by able and willing older workers. Support from management to their managers must be given especially as evidenced by the overwhelmingly positive responses from managers on their hiring intention. More so, responding managers had indicated the lack of support from their management and peers and the lack of resources had resulted in their inability to connect to their hiring intention.

\section{Public Policy Implication and Contribution}

From the empirical results obtained, responding managers perceived the lack of resources greatly reduced their intention to hire older workers. All these hampered managers' hiring intention and they are not in line with the government's effort to fill job vacancies with older workers. The above discussion points towards several public policy areas which the nation's public policymakers should address. The empirical 
result implicates policymakers to urgently review employment-related policies such as anti-age discrimination (Doron, Numhauser-Henning, Spanier, Georgantzi \& Mantovani, 2018) to ensure that employers, in general, are willing to hire older workers so that government could relieve itself from the heavy financial burden to take care of unemployed older persons. Besides, relevant authorities can consider formulating age awareness programs through educational and promotional activities for the public.

Another area worth considering would be the promotion of positive attitudes towards older persons through interaction and intergenerational contact, as stated in Naegele, Tavernier, and Hess (2018), even in advanced countries with comprehensive laws and regulations to protect the employment of older workforce, older workers still faced rejection in seeking employment. As societal and family structural evolve, the accompanying changes reduce interaction between younger persons and their older generation. Public policymakers are recommended to find ways to disseminate challenges associated with the ageing workforce to organizations and to promote joint activities between the generations via educational programs. Another publicity program is on age stereotypes and ageism campaigns which aim to reduce negative attitudes towards older persons.

\section{Research Limitation and Future Research Directions}

Given the exploratory nature of this study, there are some theoretical and methodological limitations. From the empirical results and discussions, several possible ways for future development are provided hereunder. This present study did not measure respondents' actual hiring behaviour due to the complexity associated with the collection of data within organizations and the difficulty of preserving anonymity. Due to the limited amount of longitudinal research on managers' actual hiring behaviour in academic study, wherever possible, longitudinal research to study the specific hiring intention into actual hiring behaviour would be most recommended. Ideally, results should be computed for the overall sample and every individual company for comparative study.

This study only surveyed managers with hiring authority, recruitment policy-makers or those involved in the hiring decision. Nonetheless, older workers' perceptions of hiring were ignored. Furthermore, hiring intention may have been over-generalised with 9 locations of study instead of all the states in Malaysia. As such, this study could be replicated to test the validity of the findings to those omitted locations. Male and female workers played different roles in business organizations, and given their different skills and abilities, the gender issue of older workers and the intentions of managers to hire a particular gender was not researched. Future study should research into whether managers' intention to hire older workers is affected by older workers' gender, educational attainment and health or skill levels.

\section{Conclusion}

This study has presented a systematic analysis of the investigation of the antecedents and outcomes of managers' hiring intention. Results suggested that TPB is an appropriate theory to predict hiring intention. This study's empirical results and the application of the modified TPB model were well supported by data, and the results further confirmed the relationships of the antecedents and the hiring intention, except $\mathrm{H} 3 \mathrm{~b}$ was found to be not supported. The data reported may be further taken to encourage managers to eliminate any negative attitude and subjective norm on workers due to their ages. The modified TPB explicated a better understanding of managers' intention to hire older workers.

This study has the potential to make a considerable contribution to Malaysian literature on older workers and managers' hiring intention in business organizations, as well as among public policymakers. Further research is recommended to examine the impact of other related factors on older workers and hiring managers. As the population continues to age, the baby boomer generation continues to retire early, additionally, the birth rate consistently remains low, labour is expected to persistently run short. The time has now come for business organizations to develop new policies and practices aim specifically to increase the employment of older workers especially those with skills and experiences to contribute 
significantly to economic growth. This current research has in a way bridged the literature gaps in the prediction of managers' hiring intention.

\section{References}

Abrams, D., Swift, H. J., \& Drury, L. (2016). Old and unemployable? How age-based stereotypes affect willingness to hire job candidates. Journal of Social Issues, 72, 105-121.

Ajzen, I. (1985). From intentions to action: A theory of planned behavior. In Kuhl, J., \& Beckman, J. (Ed.), Action-control: From cognition to behavior, (pp. 11-39). Heidelberg: Springer.

Ajzen, I. (1991). The theory of planned behavior. Organizational Behavior and Human Decision Process, $50,179-211$.

Ajzen, I. (2002b). Constructing a TPB questionnaire: Conceptual and methodological considerations. (Revised January, 2006). Retrieved June 5, 2016, from http://www.unibielefeld.de/ikg/zick/ajzen\%20construction\%20a\%20tpb\%20questionnaire.pdf

Ajzen, I., \& Fishbein, M. (2000). Attitudes and the attitude-behavior relation: Reasoned and automatic processes. In Stroebe, W., \& Hewstone, M. (Ed.), European Review of Social Psychology, 11, 133. John Wiley \& Sons.

Ang, M. C. H., Ramayah, T., \& Amin, H. (2015). Efficacy of the theory of planned behaviour in the context of hiring Malaysian with disabilities. The Journal of Developing Areas, 49(3), 3-25.

Ang, R. P., \& O. J. (2012). Association between caregiving, meaning in life, and life satisfaction beyond 50 in an Asian sample: Age as a moderator. Soc Indic Res, 108, 525-534.

Bagozzi, R. P., \& Yi, Y. (1988). On the evaluation of structural equation models. Journal of the Academy of Marketing Science, 16(1), 74-94.

Bal, P. M., De Lange, A. H., Jansen, P. G. W., Van Der Velde, M. E. G. (2008). Psychological contract breach and job attitudes: A meta-analysis of age as a moderator. Journal of Vocational Behavior, 72, 143-158.

Baron, R. M. \& Kenny, D. A. (1986). The moderator-mediator variable distinction in social psychological research: Conceptual, strategic, and statistical considerations. Journal of Personality and Social Psychology, 51(6), 1173-1182.

Brothers, A., Miche, M., Wahl, H. W., \& Diehl, M. (2017). Examination of associations among three distinct subjective aging constructs and their relevance for predicting developmental correlates. The Journals of Gerontology: Series B, 72(4), 547-560.

Chin, W. W. (1998a). Issues and opinion on structural equation modelling. MIS Quarterly, 22(1), 7-16.

Chin, W. W. (1998b). The partial least squares approach to structural equation modelling. In Marcoulides, G. A. (Ed.), Modern Methods for Business Research (pp. 295-358). Mahwah, NJ: Erlbaum.

Chiu, W. C. K., Chan, A. W., Snape, E., \& Redman, T. (2001). Age stereotypes and discriminatory attitudes towards older workers: An east-west comparison. Human Relations, 54(5), 629-661.

Dawson, J. F. (2014). Moderation in management research: What, why, when, and how. Journal of Business and Psychology, 29(1), 1-19.

Doron, I., Numhauser-Henning, A., Spanier, B., Georgantzi, N., \& Mantovani, E. (2018). Ageism and anti-ageism in the legal system: A review of key themes. In Ayalon, L. \& Tesch-Römer, C. (Eds.), Contemporary perspectives on ageism: Vol. 19. International perspectives on aging (pp. 303320). Berlin: Springer.

Earl, C., Taylor, P., \& McLoughlin, C. (2017). Recruitment and selection of older workers. Encyclopedia of Geropsychology, DOI 10.1007/978-981-287-082-7.

Eleventh Malaysia Plan (2016-2020). Putrajaya, Malaysia.

Fichten, C. S., Nguyen, M. N., Amsel, R., Jorgensen, S., Budd, J., Jorgensen, M., Asuncion, J., \& Barile, M. (2014). How well does the Theory of Planned Behavior predict graduation among college and university students with disabilities? Soc Psychol Educ, 17, 657-685. DOI 10.1007/s11218-0149272-8.

Fisher. G. G., Truxillo, D. M., Finkelstein, 1. M., \& Wallace, L. E. (2017). Age discrimination: Potential for adverse impact and differential prediction related to age. Human Resource Management Review 27 (2), 316-327. 
Fraser, R., Ajzen, I., Johnson, K., Hebert, J., \& Chan, F. (2011). Understanding employers' hiring intention in relation to qualified workers with disabilities. Journal of Vocational Rehabilitation, 35, 1-11.

Hair, J. F., Hult, G. T. M., Ringle, C. M., \& Sarstedt, M. (2014). A primer on partial least squares structural equation modeling (PLS-SEM). (1st ed.). California: Sage.

Hansen, T., Jensen, J. M., \& Solgaard, H. S. (2004). Predicting online grocery buying intention: a comparison of the theory of reasoned action and the theory of planned behaviour. International Journal of Information Management, 24, 539-550.

Hassell, B. L., \& Perrewe, P. L. (1995). An examination of beliefs about older workers: do stereotypes still exist? Journal of Organizational Behavior, 16, 457-468.

Heyma, A., Werff, S., Nauta, A., \& Sloten, G. (2014). What makes older job-seekers attractive to employers? De Economist, 162, 397-414.

Karpinska, K., Henkens, K., \& Schippers, J. (2013). Retention of older workers: Impact of managers' age norms and stereotypes. European Sociological Review, 29(6), 1323-1335.

King, M. (2017). Bank Negara Malaysia annual report 2016: Malaysia's 2017 current account surplus expected to narrow. Retrieved March 25, 2016, from: http://www.malaysiastock.biz/Blog/BlogArticle.aspx?tid=5002

Kline, R., B. (2011). Principles and practice of structural equation modelling (3rd ed.). New York: The Guilford Press.

Kumar, A. (2019). Exploring young adults' e-waste recycling behaviour using an extended theory of planned behaviour model: A cross-cultural study. Resources, Conservation \& Recycling, 141, 378-389.

Kunze. F., \& Menges, J. I. (2016). Younger supervisors, older subordinates: An organizational-level study of age differences, emotions, and performance. Journal of Organizational Behavior, 38(4), 461486.

Ladtika, S. B., Fischer M., Laditka, J. N., \& Segal, D. R. (2004). Attitudes about aging and gender, among young, middle age, and older college-based students. Educational Gerontology, 30(5), 403-421.

Lau, C., Choong, C. K., \& Wong, K. L. (2018). An empirical study of managers' intention to hire older workers. Journal of Business and Social Review in Emerging Economics, 4(2), 173-184.

Lev, S., Wurm, S., \& Ayalon, L. (2018). Origins of ageism at the individual level. In Ayalon, L., \& Tesch-Römer, C. (Eds.), Contemporary perspectives on ageism: Vol. 19. International Perspectives on Aging. (pp. 51-72). Berlin: Springer.

Liébana-Cabanillas, F., Sánchez-Fernández, J., Muñoz-Leiva, F. (2014). Antecedents of the adoption of the new mobile payment systems: The moderating effect of age. Computers in Human Behavior, 35, 464-478.

Lu, L., \& Kao, S. F. (2010). Attitudes towards old people and their relation to career choices among Taiwanese university students. Journal of Education and Psychology, 33, 33-54.

Lu, L., Kao, S. F., \& Hsieh, Y. H. (2011). Attitudes towards older people and Managers' intention to hire older workers: A Taiwanese study. Educational Gerontology, 37(10), 835-853.

Mohd Isa, S. \& Wong, K. Y. (2015). Age differences in behavioural intention to use internet marketing: A comparative study between Malaysian and Taiwanese. International Journal of Business and Society, 16(3), 386-396.

Muhamad Hanapiyah, Z., Daud, S., \& Wan Abdullah, W. M. T. (2018). Leadership and Corruption: Employee Compensation as Mediator and Employee Age as Moderator. Global Business and Management Research: 10 (3). (Special Issue).

Naegele, L., Tavernier, W. D., \& Hess, M. (2018). Work environment and the origin of ageism. In Ayalon, L. \& Tesch-Römer, C. (Eds.), Contemporary perspectives on ageism: Vol. 19. International perspectives on aging, (pp.73-90). Berlin: Springer.

Nedkovski, V., Guerci, M., De Battisti, F., \& Siletti, E. (2017). Organizational ethical climates and employee's trust in colleagues, the supervisor, and the organization. Journal of Business Research, $71,19-26$.

$\mathrm{Ng}$, T. W. H., \& Feldman, D. C. (2013). A meta-analysis of the relationships of age and tenure with innovationrelated behaviour. Journal of Occupational and Organizational Psychology, 86, 585-616. 
Park, N., \& Yang, A. (2012). Online environmental community members' intention to participate in environmental activities: An application of the theory of planned behaviour in the Chinese context. Computers in Human Behavior, 28, 1298-1306.

Paswan, A. K., Gai, L., \& Jeon, Sua. (2015). Alcohol and college students: Reasons, realization and intention to quit. Journal of Business Research, 68, 2075-2083.

Ringle, C. M., Wende, S., \& Becker, J. M. (2015). "SmartPLS3." Boenningstedt: SmartPLS GmbH, http://www.smartpls.com.

Rudolph, C. W., Toomey, E. C., \& Baltes, B. B. (2017). Considering age diversity in recruitment and selection: An expanded work lifespan view of age management. In E. Parry, J. \& McCarthy (eds.), The Palgrave Handbook of Age Diversity and Work, (chapter 25, pp. 607-638).

Salah, H. M. R., \& Habtoor, N. (2015). Libyan managers' perspective on the intention to retain older employees in the corporate sectors in Libya. International Journal of Management Sciences, Research Academy of Social Sciences, 6(6), 282-290.

Sekaran, U., \& Bougie, R. (2016). Research methods for business: a skill-building approach. (7th edition). John Wiley \& Sons Ltd. Chichester, West Sussex, United Kingdom.

Soulakova, J. N., Li, J., \& Crokett, L. J. (2017). Race/ethnicity and intention to quit cigarette smoking. Preventive Medicine Reports, 5, 160-165.

Tenth Malaysia Plan (2011-2015). Putrajaya, Malaysia.

Vansteenkiste, S., Deschacht, N., \& Sels, L. (2015). Why are unemployed aged fifty and over less likely to find a job? A decomposition analysis. Journal of Vocational Behavior, 90, 55-65.

White, K. M., Smith, J. K., Terry, D. J., Greenslade, J. H., \& McKimmie, B. M. (2009). Social influence in the theory of planned behaviour: the role of descriptive, injunctive, and ingroup norms. British Journal of Social Psychology, 48(1), 135-158.

Zikmund, W. G., Babin, B. J., Carr, J. C., \& Griffin, M. (2010). Business Research Methodology. (8th ed.). USA: South-Western Cengage Learning. 
